\title{
The Stock Market Reaction to Stock Dividends in Nigeria and their Information Content
}

Kevin Campbell, Division of Accounting and Finance, Stirling Management School, University of Stirling, Stirling, UK.

Chijioke Ohuocha, Financial Markets, Thomson Reuters, UK

Abstract

Purpose - To examine whether stock dividend announcements create value for companies traded on the Nigerian stock market and to ascertain the nature of the information such announcements convey.

Design/methodology/approach - A standard event study methodology, employing the market model, is applied to determine the abnormal returns both on and surrounding the stock dividend announcement date. Our sample is broken down based on the timing of announcements and on the frequency with which the announcing companies' shares are traded. We also examine the information content of stock dividends by applying the chi-square technique to test the level of association between earnings, cash dividends and stock dividends.

Findings - Our study suggests that companies that choose their own announcement date outside the Nigerian stock exchange announcement window experience positive abnormal returns if their stock is more frequently traded and negative abnormal returns if their stock is less frequently traded. In addition, support is found for both the cash substitution hypothesis and the signalling hypothesis as explanations for the information stock dividends convey to shareholders.

Research limitations/implications - The small number of companies in the 'early announcement' group may not permit a definitive view to be established about the stock market reaction to early stock dividend announcements for this group of companies.

Practical implications - The findings are of practical relevance to researchers, practitioners and investors interested in companies listed on the Nigerian stock market as they reveal the extent to which the shares reflect fundamental information from corporate announcements.

Originality/value - This study adds to the very limited academic research on the stock market reaction to stock dividend announcements in Nigeria.

Keywords: Abnormal returns, stock dividends, concurrent events, Nigerian stock market, cash substitution hypothesis and signalling hypothesis.

Paper type: Research paper 


\section{Introduction}

The impact of stock dividend announcements on the value of the firm remains a puzzle. According to Miller and Modigliani (1961) the value of a firm is not affected by the dividend policy of the firm. They argued that investors can undo any dividend policy effect without changing the value of the firm. However, contrary to their theoretical assumption, empirical studies of the impact of stock dividends on share prices show that significant price reactions occur on the announcement day (see e.g. Fama, Fisher, Jensen and Roll [hereafter FFJR] 1969; Grinblatt, Masulis and Titman, 1984; Liljeblom, 1989; McNichols and Dravid, 1990; and Woolridge, 1983).

Numerous suggestions have been offered to explain the nature of the share price reaction to stock dividend announcements, among which the signalling hypothesis is prominent. This hypothesis suggests that stock dividends are used by firms to reduce the information asymmetry between managers and investors about future earnings (Grinblatt et. al. 1984; McNichols and Dravid, 1990). Alternative explanations include: (i) the cash substitution hypothesis, which suggests that companies issue stock dividends as a substitute for cash dividends in order to conserve their cash reserves (Ghosh and Woolridge, 1989); (ii) the 'attention-getting' hypothesis, which suggests that managers split their shares so as to attract the attention of financial analyst and investors (Grinblatt et. al., 1984); (iii) the liquidity hypothesis which suggests that managers declare stock

dividends to increase the liquidity of their shares (Lakonishok and Lev, 1987); and (iv) the normal trading range hypothesis, which suggests that managers split their shares in order to move the price into a particular trading range (Ikenberry, Rankine and Stice, 1996). 
Despite the volume of research conducted on the impact of stock dividends on share prices there is only one study of stock dividends on the Nigerian market. Olowe (1998) investigated the share price reaction to stock dividends around ex-dates in Nigeria from 1981 - 1992 using monthly data. He observed that share prices react to stock dividends before and after the ex-dates, though he did not take into account the effect of other announcements that occurred before the stock dividend ex-dates. The aim of this study is to examine the impact of stock dividends on share price in Nigeria by investigating abnormal returns on the announcement dates using daily stock returns from 2002 - 2006 and also to ascertain the nature of the information conveyed by stock dividends in Nigeria by testing the cash substitution and signalling hypotheses. As well as being timely in view of a growth in the popularity of stock dividends in Nigeria in recent years, our study is also important because it takes account of a novel feature of the Nigerian environment, namely the tendency of many company announcements to occur outside the official stock exchange announcement window. We therefore examine the extent to which the market reaction to late stock dividend announcements differs from the market reaction to those announcement that occur within the official window. Given the importance of liquidity as a possible motive for stock dividends, and the thin trading that is characteristic of the Nigerian stock market, we also examine the extent to which the frequency of trading affects our results.

This paper is structured as follows: section 2 reviews the literature on stock dividend announcements. Section 3 describes the nature of stock dividends in Nigeria, while section 4 presents the data and the methodology used to conduct the study. Section 5 discusses the results and section 6 concludes the study. 


\section{Literature Review}

The literature is reviewed in two parts. The first examines the impact of stock dividend announcements on stock market returns in the context of the efficient market hypothesis while the second reviews studies of the information content of stock dividends. According to the seminal work of FFJR (1969) on the stock market reaction to the announcement of stock splits in the US, for markets to be efficient share prices must fully reflect all available information contained in the stock split on the announcement day. This means that share prices are expected to adjust quickly to the split information and not exhibit any price drift before or after the announcement, from which abnormal returns can be earned. Testing their hypothesis on monthly share price data from the US market using the event study methodology, which they popularised, they found that stock splits caused share price reactions but only to the extent that the split information was new and unanticipated. Thus, they confirmed the proposition that markets are efficient in the sense that prices adjust very quickly to new information.

Many researchers have examined the impact of stock dividends on share prices in different markets from the time of FFJR's (1969) work to the present, applying the same event study methodology. The results of their studies are similar to those reported by FFJR (1969) and support the notion that share prices react to stock dividend announcements (see Woolridge, 1983; Grinblatt et al., 1984; Lamoureux and Poon, 1987; Doran and Nachtmann, 1988; McNichols and Dravid, 1990; Banker, Das and Dater, 1993; Aydogan and Muradoglu, 1998; Olowe, 1998; Anderson, Cahan and Rose, 2001; Elfakhani and Lung, 2003; Balachandran, Faff and Tanner, 2004; Farinha and Basilio, 2006; Leung, Rui and Wang, 2006; Lyroudi and Dasilas, 2006; Bechmann and Raaballe, 2007; and Dhar and Chhaochharia, 2008). [1] 
Despite this weight of evidence, a non-US study covering the period 1981-94 by Papaionnou, Travlos and Tsangarakis (2000) on the share price reaction to stock dividends in Greece did not find any evidence in support of a share price reaction. Instead, they found that stock dividends did not contain any information content as they mostly arise in Greece from a legal requirement to give effect to the capitalization of reserves form asset revaluations. They argue that the absence of the "surprise element" weakens the information content of stock dividend announcements and so share prices do not react due to the absence of new information (Papaionnou et al., 2000). However, despite this feature of the Greek market, a recent study by Leledakis, Papaioannou, Travlos, and Tsangarakis (2009) covering the period 1990-2000 did uncover a positive price reaction around stock dividend announcements in Greece, which they attribute to the 'attention-getting' and normal trading range hypotheses.

As far as Nigeria is concerned, part of the reason for the dearth of stock dividends studies lies in the inadequacy of historic share price records and the absence of a database containing corporate actions. Nevertheless, Olowe (1998) examined share price reactions to stock splits in Nigeria around ex-dates from 1981 - 1992 using monthly data. He observed that share prices react to stock splits before and after ex-dates in Nigeria. He explained this by suggesting that investors did not anticipate the event and so share prices did not adjust quickly after the split. However, he did not take into account other information which could have been announced at the same time as the stock dividend ex-dates.

The empirical findings of FFJR (1969) and other recent studies support the notion that share prices react to stock dividend announcements even when stock dividends in themselves do not 
contain any apparent new information. The question that follows is: what causes the share price reaction to stock dividend announcements? The presumption is that the "surprise element" in stock dividend announcements contains information that is more fundamental to share prices than just the additional shares declared. According to FFJR (1969): “stock dividends are associated with substantial cash dividend increases which the market realises and uses to re-evaluate the stream of expected income from the shares” ( $p$ 25). Thus, when stock dividends are announced, share prices react in expectation of future cash dividend increases. Moreover, the stock dividend effect on share prices weakens if the announcement is associated with a cash dividend decrease. This evidence suggests that share prices react to the future cash dividend implication of stock dividend announcements.

A number of researchers have investigated the information content of stock dividend announcements and have substantiated the finding of FFJR (1969) that share prices react to the signalling content implicit in stock dividend announcements, which they refer to as the signalling hypothesis (see Grinblatt et al., 1984; McNichols and Dravid, 1990; Elfakhani and Lung, 2003; Balachandran et al. 2004; Leung et al., 2006; and Dhar and Chhaochharia, 2008). For example Grinblatt et al. (1984) examined the information content of stock dividend announcements in the US from 1967 - 1976 and concluded that managers conveyed favourable private information concerning future earnings to investors through stock dividend announcements. However, managers refrain from stock dividend announcements when future earnings are uncertain, so as not to signal negative information to investors. Thus, the signalling hypothesis is one of the most compelling explanations, among others, for the stock market's reaction to stock dividend announcements. 
Alternative hypotheses proposed by researchers to explaining the information content of stock dividends, apart from the signalling hypothesis, include the cash substitution hypothesis, the 'attention-getting' hypothesis, and the 'normal trading range' hypothesis. The cash substitution hypothesis suggests that companies issue stock dividends as a temporary substitute for cash dividends in order to conserve their cash reserves. Empirical studies provide some limited support for this hypothesis. For example, Ghosh and Woolridge (1988) found that a negative stock market reaction to dividend cuts and omissions by U.S. firms could be offset or reduced by an announcement of a stock dividend as a substitute. Banker et al. (1993) examined the stock market reaction to firms in the U.S. that discontinued cash dividends while maintaining their existing level of stock dividends. They found a positive (although statistically insignificant) abnormal return following such announcements. In a study of Chinese stock market reactions, Chen, Firth and Gao (2002) provide some evidence that stock dividends appear to be favoured over cash dividends. Despite the results of these studies, there are also many cases where firms issuing stock dividends also continue to pay the same cash dividend per share, effectively increasing the total cash dividends paid to shareholders, which runs contrary to the logic of the cash substitution hypothesis.

The 'attention-getting' hypothesis was proposed by Grinblatt et al. (1984) as an alternative formulation of the signalling hypothesis, to explain the positive market reaction to stock dividend announcements. They suggested that stock dividends are issued to attract attention from professional analysts and to trigger a revaluation of firms' future cash flows. This hypothesis was examined by Doran and Nachtmann (1988) in their study of U.S. firms which issued stock 
dividends and announced stock splits between 1971 and 1982. They found that immediately after the announcement of a stock dividend there was a significant positive revision in analysts' earnings expectations, lending support to the hypothesis. The liquidity hypothesis suggests that the creation of additional shares should lead to an increase in trading and greater ownership dispersion, thereby improving liquidity. However, in their study of trading volume changes after stock dividend announcements during the period 1963 to 1982 by firms listed on the NYSE and the AMEX, Lakonishok and Lev (1987) found that while trading volume increased in the announcement month, this volume increase did not persist. Lack of evidence for the liquidity hypothesis is also reported in Bechmann and Raaballe (2007) for Danish stocks. In contrast, however, a study of Canadian stock splits between 1973 and 1992 by Elfakhani and Lung (2003) found that both trading volumes and earnings increased, post split, and a study by Lyroudi and Dasilas (2006) of firms listed on NASDAQ between 1999 and 2000 found evidence of a positive market reaction to stock split announcement consistent with the liquidity hypothesis, albeit based on a small sample (57 observations).

The 'normal trading range' hypothesis suggests that because stock dividends and stock splits engineer a decrease in the stock price, it falls into an optimal trading range that results in an expansion of the investor base and hence a positive re-evaluation of the stock. Several studies, including those of Lakonishok and Lev (1987), McNichols and Dravid (1990), and Ikenberry et al. (1996) find that stock splits and stock dividends follow stock price run-ups that push share prices above the normal range for peer groups. In their study of U.S. stock splits from 1975 to 1990, Ikenberry et al. (1996) suggest that the preference for a normal trading range leads firms to self-select a lower post-split target price the more optimistic they are about their future share 
prices, generating a signalling effect associated with the post-split target price. Their evidence of an inverse relationship between post-split target prices and the market reaction to stock splits is consistent with this hypothesis.

Many emerging markets, including Nigeria, are characterised by thinness of trading where corporate information is often neither reliable nor available to all traders, so stock dividends may not convey information in the same way as they do in developed markets. Aydogan and Muradoglu (1998) investigated the market reaction to stock dividend announcements by firms listed on the Istanbul Stock Exchange. They divided their sample into two subperiods: 19881990, when firms did not have to inform the exchange immediately after corporate decisions; and 1991-1993, when the market became more mature and all listed firms were obliged to make timely public disclosures of all significant corporate decisions. Significant positive price reactions were observed in the first subperiod but not in the second subperiod, interpreted by the authors as a sign of market efficiency as the market matured. The price reactions in the initial subperiod were attributed to the absence of timely information about company fundamentals, so that stock dividends conveyed information about future profitability or confirmed that previously realized earnings were permanent.

In a nutshell, the empirical evidence on the impact of stock dividends on share prices is extensive, with minor contradictions based on market microstructure, and with many researchers explaining the information content of stock dividend announcements in terms of the signalling hypothesis. 


\section{Stock dividends in Nigeria}

Stock dividends are known as bonus issues in Nigeria. They involve the distribution of additional shares to investors whose names appear on the company's register of members before a certain cut-off date (the ex-date) that is usually fixed by the company. The additional shares are given to investors "free of charge" while the share price is diluted on the ex-date by the bonus ratio to reflect the additional shares.

Bonus issues increase the number of shares outstanding according to the bonus ratio without changing the equity value of the firm. This means that the assets of the company are divided by an increased number of shares outstanding as a result of the bonus shares. In Nigeria, investors who qualify for bonus issues receive the additional shares approximately two week after the exdate. The bonus shares are transferred electronically to their stock broking accounts and they can trade them immediately. The decision to issue bonus shares in Nigeria is entirely at the discretion of the board of directors of the company, subject to shareholders' ratification at the Annual General Meeting. The articles of association authorise the company's action regarding the distribution of bonus shares while the provisions of the law only specify the type of reserves which companies can use to issue bonus shares. According to the Company and Allied Matters Act (CAMA) 1990 section 120 subsection 3, companies can only distribute bonus shares from their share premium account. This implies that companies have to capitalise their share premium reserves each time they declare bonus shares. Companies typically justify the issue of bonus shares in Nigeria as a means of rewarding shareholders. 
Figure 1: NSE Index and Stock Dividends from 2002 - 2006

- $\quad$ Insert Figure 1 here -

The growing popularity of stock dividends in recent year is evident from Figure 1, which shows an upward trend in the number of bonus issues per year from 2002 to 2006 (right hand scale) irrespective of the closing value of the NSE Index (left hand scale). Stock dividends are announced simultaneously with earnings and cash dividends at the companies' financial year-end in Nigeria. However, the timing of announcements are not known with complete certainty because the majority of listed companies choose their own announcement dates despite the Nigerian Stock Exchange guidelines on announcements. [2] Companies trade off the timeliness of announcements with the payment of fines (of about US\$900) to the stock exchange, which is not sufficient to ensure compliance.

\section{Data and Methodology}

The share price, stock index, dividends and earnings data for this study were obtained from the African Financial markets database (www.africanfinancialmarkets.com) and stock dividend announcement dates from 2002 - 2006 were obtained from the Nigerian Stock Exchange library. All listed companies that announced stock dividends during this period and which had a stock exchange listing for at least twelve months before and after the announcement were included in our sample. [3] A total of 132 stock dividends were announced on the Nigerian stock market by 73 listed companies over the sample period. Of these, 21 announcement dates were missing from the NSE library, while there were 4 multiple announcement dates and 8 announcement dates that occurred before companies' financial year-ends. The deletion of these cases produced a final sample of 99 stock dividend announcements from 60 companies. [4] 
We use a standard event study methodology to investigate the share price reaction to stock dividend announcements in Nigeria, following the approach of Seiler (2004). [5] The estimation period for the event study comprises 100 days, measured from day -115 prior to the stock dividend announcement day (day 0 ) until day +16 . The event (test) period comprises a total of 31 days, measured from day -15 to day +15 after the stock dividend announcement. The daily stock prices of the sample companies listed on the Nigerian stock market are used to calculate daily stock returns, while the Nigerian Stock Exchange All-Share Index (a value-weighted index) is used to calculate daily stock market returns. Daily stock price returns for each of the companies are calculated using logarithmic returns as follows:

$$
\mathrm{R}_{\mathrm{jt}}=\ln \left(\mathrm{P}_{\mathrm{jt}} / \mathrm{P}_{\mathrm{jt}-1}\right)
$$

Where $\mathrm{R}_{\mathrm{jt}}=$ Stock return of company $\mathrm{j}$ at time $\mathrm{t}$

$$
\begin{aligned}
& \mathrm{P}_{\mathrm{jt}}=\text { Sock price of company } \mathrm{j} \text { at time } \mathrm{t} \\
& \mathrm{P}_{\mathrm{jt}-1}=\text { Stock price of company } \mathrm{j} \text { at time } \mathrm{t}-1
\end{aligned}
$$

Stock price returns calculated from the above formula provided the total returns for the sample companies as share prices are automatically adjusted for cash dividends and stock dividends by the NSE on ex-dates. Daily logarithmic returns are also calculated for the stock market using the NSE All-share index data.

Abnormal returns are calculated using the market model, which is commonly used in event studies to measure abnormal returns (Strong, 1992). Expected returns are modelled as follows: 


$$
\mathrm{E}\left(\mathrm{R}_{\mathrm{jt}}\right)=\alpha_{\mathrm{j}}+\beta_{\mathrm{j}} \mathrm{R}_{\mathrm{mt}}+\mathrm{e}_{\mathrm{jt}}
$$

Where $E\left(R_{j t}\right)=$ Expected return of firm $\mathrm{j}$ at time $\mathrm{t}$

$$
\mathrm{R}_{\mathrm{mt}}=\text { Stock market return at time } \mathrm{t}
$$

$\alpha_{j}$ and $\beta_{j}=$ alpha and beta of firm $\mathrm{j}$

$$
\mathrm{e}_{\mathrm{jt}}=\text { residual term for firm } \mathrm{j} \text { at time } \mathrm{t}
$$

Abnormal returns are calculated as $\mathrm{AR}_{\mathrm{jt}}=\mathrm{R}_{\mathrm{jt}}-\mathrm{E}\left(\mathrm{R}_{\mathrm{jt}}\right)$. These are then measured across the event date $\mathrm{t}$ for all firms and standardized as follows:

$$
\mathrm{SAR}_{\mathrm{jt}}=\sum \mathrm{AR}_{\mathrm{jt}} /\left(\mathrm{s}^{2} \mathrm{AR}_{\mathrm{jt}}\right)^{1 / 2}
$$

Where $\mathrm{SAR}_{\mathrm{jt}}=$ Standardized abnormal returns for firm $\mathrm{j}$ at time $\mathrm{t}$

$$
\begin{aligned}
& \mathrm{s}^{2} \mathrm{AR}_{\mathrm{jt}}=\text { Variance of the abnormal returns for firm } \mathrm{j} \text { at time } \mathrm{t} \\
& \mathrm{t}=-115<\mathrm{t}<-16
\end{aligned}
$$

The next step is to aggregate the SARs for each separate day in the event window and determine if the results are significant as a Total Standardized Abnormal Return (TSAR). Then cumulative total standardized abnormal returns (cumulative TSARs) for each day are computed as:

$$
\operatorname{CTSAR}_{T_{1}, T_{2}}=\sum_{t=T_{1}}^{T_{2}} T S A R_{t}
$$

Where

$C T S A R_{T_{1}, T_{2}}=$ cumulative TSAR for each day in the event window

$\mathrm{TSAR}_{\mathrm{t}}=\mathrm{TSAR}$ for each day in the event window

$\mathrm{T}_{1}=$ earliest date in the event window $(\mathrm{t}=-15)$ 
$T_{2}=$ later date in the event window (ranges from $t=-15$ through $t=+15$ )

The significance level for the TSAR is tested using the $\mathrm{Z}$ - statistic, as follows:

$$
\mathrm{Z}-\text { statistic }_{\mathrm{t}}=\mathrm{TSAR}_{\mathrm{t}} /\left(\sum_{\mathrm{J}=1}^{\mathrm{N}} \mathrm{D}_{\mathrm{j}}-2 / \mathrm{D}_{\mathrm{j}}-4\right)^{1 / 2}
$$

Where $D_{j}=$ number of observed trading day returns for firm $j$ over the estimation period.

$$
\mathrm{N}=\text { number of firms in the sample. }
$$

Non-trading, or infrequent trading, biases the estimate of beta downwards when measuring abnormal returns (Dimson, 1979). Shares listed on the Nigerian stock market suffer from varying degrees of non-trading or infrequent trading, attributable to the market microstructure and the concentrated ownership structure of companies. In this study, beta estimates are adjusted for infrequent trading using the Aggregate Coefficient Method (Dimson, 1979) [6].

The information content of stock dividends in Nigeria is also examined using the chi-square test and correlation analysis. The chi-square test is used to determine the level of independence between unexpected earnings and cash and stock dividends respectively, while the correlation analysis is used to investigate the level of interaction between them (following Chen et. al., 2002). The chi-square analysis used in this study is calculated as follows:

$$
\text { Chi-square test }\left(\mathrm{X}^{2} \text { cal }\right)=\sum \frac{(\mathrm{O}-\mathrm{E})^{2}}{\mathrm{E}}
$$

Where $\mathrm{O}=$ Observed number of unexpected earnings and unexpected dividend changes by their signs.

$\mathrm{E}=$ Expected number of unexpected earnings and unexpected dividend changes by their signs. 
The final sample of 99 stock dividend announcements is split into two sub-samples based on the timing of the announcements ("early" and "late"). The first sub-sample consists of 10 announcements made in accordance with the NSE rules and the second consists of 89 announcements made by companies choosing later dates. Because of infrequent trading, the final sample is also broken down based on trading frequency during the event estimation period (details are provided in Table 1) [7]. Given that the issuance of stock dividends may bring the stock price down into a preferred trading range, and thus increase trading frequency, we split our sample based on pre-event trading frequency to ascertain the extent to which the impact of stock dividend announcements may vary according to existing levels of liquidity.

The announcements were split into quintiles based on the percentage of days in the estimation period when the announcing company's stock was traded. Of the 99 announcements, the 23 in the lowest quintile are not examined further due to the severity of infrequent trading, while the remaining 76 are split into two groups. The first group contains announcement by companies whose shares were traded on more than 60 per cent of the days in the estimation period (the first two quintiles) while the second group contains companies whose shares were traded on more than 20 per cent and less than or equal to 60 percent of the days in the estimation period (the third and fourth quintiles). The final sample is thus broken down based on both the timing of announcements and the frequency of trading. As all of the early announcement companies had their stock traded on more than 60 per cent of the days during the estimation period, only the late announcement group was broken down on the basis of trading frequency. 
Table I: Trading frequency of stocks during the estimation period

\begin{tabular}{|c|c|}
\hline Trading frequency & Number of Announcements \\
\hline $81-100$ & 36 \\
\hline $61-80$ & 13 \\
\hline $21-60$ & 18 \\
\hline $1-40$ & 9 \\
\hline \multicolumn{2}{|c|}{$\begin{array}{c}\text { Notes: Trading frequency refers to the percentage of days that } \\
\text { the stock is traded in the event estimation period. }\end{array}$} \\
\hline
\end{tabular}

Source: African Financial Markets Database and Authors' computations 


\section{Results}

We first consider the stock market impact of stock dividend announcements and then go on to assess the nature of the information content embedded in these announcements. The event day abnormal returns for all 99 announcements, and for the subsamples of 10 early and 89 late announcements, were all found to be insignificantly different from zero. The subsample of 89 late announcements was further investigated on the basis of the trading frequency of the announcing companies during the estimation period, even though the stock betas used in calculating the abnormal returns were adjusted using the Dimson Aggregate Coefficient Method. In his study of stock splits in Nigeria, Olowe (1998) performed a similar check for the impact of trading frequency on abnormal returns and found that the abnormal returns of both frequently and infrequently traded shares were similar, although he did not adjust for infrequent trading.

It can be seen from Table II below that the total standardized abnormal returns (TSARs) for frequently traded companies that announce stock dividends late are consistently positive from day $\mathrm{t}-4$ to day $\mathrm{t}+4$ and are statistically significant on the event day. The abnormal return on day $\mathrm{t}=0$ is 14.7 per cent, indicating that the stock market reacts positively to late stock dividends announced by companies outside the official trading window whose shares are more frequently traded. Moreover, the CTSARs are statistically significant from 11 days before the announcement until 9 days after, implying that these late stock dividend announcements were anticipated before their occurrence. This suggests that investors receive information about late stock dividend announcements from the "grapevine” before the news becomes public knowledge. 
Table II: Abnormal returns for frequently traded companies $(\mathrm{N}=41)$

\begin{tabular}{|c|c|c|c|c|c|c|}
\hline Days & TSAR & Z- statistic & p-value & $\begin{array}{c}\text { Cumulative } \\
\text { TSAR }\end{array}$ & Z-statistic & $\mathrm{p}$-value \\
\hline-15 & -1.4778 & -0.2284 & 0.8193 & -1.4778 & 7.705 & $0.0000^{* *}$ \\
\hline-14 & -8.7987 & -1.36 & 0.1738 & -10.2765 & 0.2405 & 0.8099 \\
\hline-13 & 3.8914 & 0.6015 & 0.5475 & -6.3851 & 1.5051 & 0.1323 \\
\hline-12 & 4.2721 & 0.6604 & 0.509 & -2.113 & -0.8069 & 0.4197 \\
\hline-11 & 12.2532 & 1.894 & 0.0582 & 10.1402 & 26.8247 & $0.0000^{* *}$ \\
\hline-10 & 10.4198 & 1.6106 & 0.1073 & 20.56 & 32.8683 & $0.0000^{* *}$ \\
\hline-9 & 3.3497 & 0.5178 & 0.6046 & 23.9096 & 32.5133 & $0.0000 * *$ \\
\hline-8 & -1.9508 & -0.3015 & 0.763 & 21.9589 & 29.9552 & $0.0000 * *$ \\
\hline-7 & 1.3654 & 0.2111 & 0.8328 & 23.3243 & 30.7431 & $0.0000 * *$ \\
\hline-6 & 2.7741 & 0.4288 & 0.6681 & 26.0984 & 31.0517 & $0.0000^{* *}$ \\
\hline-5 & -4.6801 & -0.7234 & 0.4694 & 21.4183 & 30.0282 & $0.0000^{* *}$ \\
\hline-4 & 0.14 & 0.0216 & 0.9827 & 21.5583 & 26.342 & $0.0000 * *$ \\
\hline-3 & 4.9801 & 0.7698 & 0.4414 & 26.5385 & 29.1805 & $0.0000^{* *}$ \\
\hline-2 & 1.7053 & 0.2636 & 0.7921 & 28.2438 & 23.1288 & $0.0000 * *$ \\
\hline-1 & 12.4444 & 1.9236 & 0.0544 & 40.6881 & 34.3971 & $0.0000^{* *}$ \\
\hline 0 & 14.7126 & 2.2742 & $0.0230 * *$ & 55.4007 & 41.4613 & $0.0000 * *$ \\
\hline 1 & 3.1555 & 0.4877 & 0.6257 & 58.5562 & 43.0974 & $0.0000^{* *}$ \\
\hline 2 & 5.4639 & 0.8446 & 0.3984 & 64.0201 & 42.441 & $0.0000 * *$ \\
\hline 3 & 5.6266 & 0.8697 & 0.3845 & 69.6468 & 48.2096 & $0.0000^{* *}$ \\
\hline 4 & 2.5084 & 0.3877 & 0.6982 & 72.1551 & 40.2063 & $0.0000^{* *}$ \\
\hline 5 & -30.9651 & -4.7863 & $0.0000^{* *}$ & 41.1901 & 26.4106 & $0.0000 * *$ \\
\hline 6 & 7.6862 & 1.1881 & 0.2348 & 48.8763 & 27.9628 & $0.0000 * *$ \\
\hline 7 & -11.1016 & -1.716 & 0.0862 & 37.7746 & 23.9097 & $0.0000^{* * *}$ \\
\hline 8 & -7.5457 & -1.1664 & 0.2435 & 30.2289 & 9.995 & $0.0000^{* *}$ \\
\hline 9 & -4.0018 & -0.6186 & 0.5362 & 26.2271 & 6.6097 & $0.0000^{* *}$ \\
\hline 10 & -19.221 & -2.971 & $0.0030 * *$ & 7.0061 & -1.4592 & 0.1445 \\
\hline 11 & -5.7548 & -0.8895 & 0.3737 & 1.2512 & 1.1639 & 0.2444 \\
\hline 12 & -18.698 & -2.8902 & $0.0039 * *$ & -17.4468 & -1.1176 & 0.2637 \\
\hline 13 & -7.7332 & -1.1953 & 0.232 & -25.18 & -1.4819 & 0.1384 \\
\hline 14 & -99.6785 & -15.4075 & $0.0000 * *$ & -124.8584 & -59.1672 & $0.0000 * *$ \\
\hline 15 & 12.8354 & 1.984 & $0.0473^{* *}$ & -112.023 & -48.5482 & $0.0000 * *$ \\
\hline
\end{tabular}

As illustrated in Figure 2 below, the abnormal returns of companies announcing late stock dividends, with trading frequencies of 60 per cent and above, trend upwards before the announcement until day $t+5$ when the first sign of decline is observed. However, after day $t+10$, 
share prices adjust fully to the stock dividend announcements and resume a downwards trend thereafter.

\title{
Figure 2: CTSARs for late stock dividend announcements by companies with greater trading frequency
}

\author{
- $\quad$ Insert Figure 2 here -
}

The stock market reaction to companies with thinly traded shares that announce stock dividends outside the official stock exchange window is similar to that of companies with more frequently traded shares that announce late stock dividends, except that the abnormal return for the former is negative on the event day and afterwards. Abnormal returns build up positively from day t-11 to day t-8 and then begin to decline four days before the event date. The abnormal return is negative on the event day itself (and significant at the 5\% level) which suggests that late stock dividend announcements by companies with less frequently traded stocks cause investors to downgrade their valuation of the stock. The cumulative abnormal returns are statistically significant on all days throughout the event window, suggesting the possibility of information leakage before the announcements. Infrequent trading in Nigeria is often caused by the concentrated shareholding structure of some of the listed companies or the freezing of share prices by the NSE, called “technical suspension". In such circumstances, investors rely on inside information to trade stocks. 
Table III: Abnormal returns for thinly traded companies ( $\mathrm{N}=27)$

\begin{tabular}{|c|c|c|c|c|c|c|}
\hline Days & TSAR & Z-statistic & p-value & $\begin{array}{c}\text { Cumulative } \\
\text { TSAR }\end{array}$ & Z-statistic & p-value \\
\hline-15 & 5.8554 & 1.1153 & 0.2647 & 5.8554 & 10.24 & $0.0000^{* *}$ \\
\hline-14 & 6.2783 & 1.1959 & 0.2317 & 12.1338 & 15.2552 & $0.0000^{* *}$ \\
\hline-13 & -0.6548 & -0.1247 & 0.9007 & 11.4789 & 14.259 & $0.0000 * *$ \\
\hline-12 & -5.6159 & -1.0697 & 0.2848 & 5.863 & 2.9191 & $0.0035^{* *}$ \\
\hline-11 & 5.3721 & 1.0233 & 0.3062 & 11.2351 & 10.5935 & $0.0000^{* *}$ \\
\hline-10 & 14.4243 & 2.7475 & $0.0060 * *$ & 25.6593 & 27.9022 & $0.0000 * *$ \\
\hline-9 & 11.5886 & 2.2074 & $0.0273^{* *}$ & 37.2479 & 43.7537 & $0.0000 * *$ \\
\hline-8 & 13.1602 & 2.5067 & $0.0122 * *$ & 50.4081 & 57.7249 & $0.0000 * *$ \\
\hline-7 & -6.6693 & -1.2703 & 0.204 & 43.7388 & 58.4829 & $0.0000 * *$ \\
\hline-6 & 1.95 & 0.3714 & 0.7103 & 45.6889 & 56.6739 & $0.0000 * *$ \\
\hline-5 & 5.3673 & 1.0223 & 0.3066 & 51.0561 & 53.4161 & $0.0000 * *$ \\
\hline-4 & -14.1589 & -2.6969 & $0.0070^{* *}$ & 36.8972 & 38.4483 & $0.0000 * *$ \\
\hline-3 & -5.7907 & -1.103 & 0.27 & 31.1065 & 31.8849 & $0.0000^{* *}$ \\
\hline-2 & -5.3664 & -1.0222 & 0.3067 & 25.7402 & 25.2011 & $0.0000 * *$ \\
\hline-1 & -6.5599 & -1.2495 & 0.2115 & 19.1803 & 25.362 & $0.0000^{* *}$ \\
\hline 0 & -25.0973 & -4.7804 & $0.0000^{* *}$ & -5.917 & -6.1953 & $0.0000^{* *}$ \\
\hline 1 & -3.3493 & -0.638 & 0.5235 & -9.2663 & -10.5786 & $0.0000 * *$ \\
\hline 2 & 11.5297 & 2.1961 & $0.0281^{* *}$ & 2.2635 & -7.6058 & $0.0000^{* *}$ \\
\hline 3 & -10.1307 & -1.9297 & 0.0536 & -7.8673 & -22.9711 & $0.0000^{* *}$ \\
\hline 4 & -21.6238 & -4.1188 & $0.0000^{* *}$ & -29.4911 & -36.8979 & $0.0000^{* *}$ \\
\hline 5 & 3.6398 & 0.6933 & 0.4881 & -25.8513 & -36.5335 & $0.0000^{* *}$ \\
\hline 6 & -9.6206 & -1.8325 & 0.0669 & -35.4718 & -35.5827 & $0.0000 * *$ \\
\hline 7 & 7.4325 & 1.4157 & 0.1569 & -28.0393 & -31.2766 & $0.0000^{* *}$ \\
\hline 8 & -9.4676 & -1.8033 & 0.0713 & -37.5069 & -32.9394 & $0.0000^{* *}$ \\
\hline 9 & -2.0259 & -0.3859 & 0.6996 & -39.5328 & -32.1051 & $0.0000 * *$ \\
\hline 10 & -9.4671 & -1.8033 & 0.0713 & -48.9999 & -34.285 & $0.0000^{* *}$ \\
\hline 11 & -0.7724 & -0.1471 & 0.883 & -49.7723 & -31.9892 & $0.0000 * *$ \\
\hline 12 & -19.6417 & -3.7413 & $0.0002^{* *}$ & -69.414 & -33.2046 & $0.0000^{* *}$ \\
\hline 13 & 1.4195 & 0.2704 & 0.7869 & -67.9945 & -33.7595 & $0.0000^{* *}$ \\
\hline 14 & -33.0009 & -6.2859 & $0.0000 * *$ & -100.9954 & -49.3795 & $0.0000 * *$ \\
\hline 15 & -17.2618 & -3.288 & $0.0010^{* *}$ & -118.2572 & -52.0527 & $0.0000 * *$ \\
\hline
\end{tabular}

Figure 3 illustrates the cumulative abnormal returns on late stock dividend announcements by companies with lower trading frequencies. From Figure 3 it can be observed that abnormal 
returns trend upwards from 10 days before the announcement and then decline significantly on the announcement day, after which they trend downwards.

Figure 3: CTSARs for late stock dividend announcements by companies with lower trading frequency

- $\quad$ Insert Figure 3 here -

We now turn our attention to the information content of stock dividend announcements. The chisquare technique is used to test the level of association between earnings, cash dividends and stock dividends. Table IV reports the frequency of unexpected earnings and unexpected cash and stock dividend changes according to their signs. Panel A shows the crosstabulation of unexpected earnings and unexpected cash dividend changes; Panel B reports the crosstabulation of unexpected earnings and unexpected stock dividend changes; and Panel C reports the crosstabulation of unexpected earnings with both unexpected cash and stock dividends combined. 
TABLE IV Summary statistics of Unexpected Earnings and Unexpected Dividend changes by their signs

\section{PANEL A: Unexpected Earnings and Unexpected Cash Dividends}

Unexpected

Cash Dividend

Change (UCD)

Positive

Zero

Negative

Total
Unexpected Earnings Change (UE)

Positive Negative Total

$\begin{array}{lll}20 & 7 & 27\end{array}$

$\begin{array}{lll}7 & 7 & 14\end{array}$

2628

$29 \quad 40 \quad 69$

Chi-square test of the independence of cash dividends and earnings:

chi-square $\left(X_{\text {cal }}^{2}\right)=25.732, X_{\text {crit }}^{2}=5.990$

\section{PANEL B: Unexpected Earnings and Unexpected Stock Dividends}

Unexpected

Stock Dividend

Change (USD)

Positive

Zero

Negative

Total
Unexpected Earnings Change (UE)

Positive Negative Total

$\begin{array}{lll}25 & 34 & 59\end{array}$

$2 \quad 1 \quad 3$

$2 \quad 5 \quad 7$

$29 \quad 40 \quad 69$

Chi-square test of the independence of stock dividends and earnings:

chi-square $\left(\mathrm{X}_{\text {cal }}^{2}\right)=1.2703, \mathrm{X}_{\text {crit }}^{2}=5.990$ 


\begin{tabular}{|c|c|c|c|c|}
\hline \multicolumn{2}{|c|}{$\begin{array}{l}\text { Unexpected Dividend Change } \\
\text { (cash and stock) }\end{array}$} & \multicolumn{3}{|c|}{ Unexpected Earnings Chang } \\
\hline UCD & USD & Positive & Negative & Total \\
\hline Positive & Positive & 19 & 6 & 25 \\
\hline Positive & Zero & 1 & 1 & 2 \\
\hline Positive & Negative & 0 & 0 & 0 \\
\hline Zero & Positive & 5 & 5 & 10 \\
\hline Zero & Zero & 1 & 0 & 1 \\
\hline Zero & Negative & 1 & 2 & 3 \\
\hline Negative & Positive & 1 & 23 & 24 \\
\hline Negative & Zero & 0 & 0 & 0 \\
\hline Negative & Negative & 1 & 3 & 4 \\
\hline Total & & 29 & 40 & 69 \\
\hline
\end{tabular}

The chi-square test of the independence of total cash and stock dividends and earnings: chi-square $\left(\mathrm{X}_{\text {cal }}^{2}\right)=28.22, \mathrm{X}_{\text {crit }}=15.510$

Notes: Unexpected Earning change, $\mathrm{UE}=\left(\mathrm{E}_{\mathrm{t}}-\mathrm{E}_{\mathrm{t}-1}\right) / \mathrm{SP}_{\mathrm{d}-1}$; Unexpected Cash Dividend change, $\mathrm{UCD}=\left(\mathrm{CD}_{\mathrm{t}}-\mathrm{CD}_{\mathrm{t}-1}\right) / \mathrm{SP}_{\mathrm{d}-1} ;$ Unexpected Stock Dividend change USD $=\left(\mathrm{SD}_{\mathrm{t}}-\mathrm{SD}_{\mathrm{t}-1}\right) / \mathrm{SP}_{\mathrm{d}-1} . \mathrm{E}_{\mathrm{t}}$ and $E_{t-1}$ are the earnings per share at year $t$ and year $t-1$ respectively; $C_{t}$ and $C_{t-1}$ are the cash dividends per share at year $t$ and year $t-1$ respectively; $\mathrm{SD}_{\mathrm{t}}$ and $\mathrm{SD}_{\mathrm{t}-1}$ are the stock dividends per share at year $\mathrm{t}$ and year $\mathrm{t}-1$ respectively; and $\mathrm{Sp}_{\mathrm{d}-1}$ is the share price a day before the stock dividend announcement day.

From Panel A, we can observe that 39 per cent of firms increased cash dividends ( $\mathrm{n}=27$ ), 20 per cent did not change cash dividends ( $\mathrm{n}=14$ ), and 41 per cent decreased cash dividends ( $\mathrm{n}=28$ ). In our sample 42 per cent ( $\mathrm{n}=29$ ) of earnings surprises (proxied by increases in earnings per share) are positive and 58 per cent $(n=40)$ are negative (there were no incidences of zero earnings changes). Visual inspection suggests that firms increase cash dividends when earnings increase and decrease cash dividends when earnings decrease. The test of association between earnings and cash dividends using the chi-square test, reported in Panel A, rejects the null hypothesis of independence, which suggests that unexpected earnings and cash dividend changes are associated 
(the correlation coefficient between them is 0.1761 , which is higher than the value of 0.115 reported by Chen et. al., 2002). [8]

The pattern observed in panel B for unexpected stock dividends is different to that observed in panel A for unexpected cash dividends. In panel B, 86 per cent of firms increased stock dividends $(n=59), 4$ percent made no change $(n=3)$, and 10 per cent decreased stock dividends $(n=7)$ during the same period. Moreover, visual inspection of Panel B suggests that increases and/or decreases in unexpected stock dividends occur evenly for both positive and negative changes in unexpected earnings respectively. The chi-square test of association between unexpected earnings and stock dividends indicates that they are unrelated (the correlation coefficient of 0.0729 is similar to the 0.074 coefficient obtained by Chen et al., 2002). [9]

The difference in the patterns observed in panels A and B suggests that cash and stock dividends may be substitutes (Ghosh and Woolridge, 1989; Banker et al., 1993; Chen et al., 2002). The correlation between cash and stock dividends is 0.1424 for the total sample of 69 companies and 0.1756 for the sample with zero cash and stock dividend payments omitted. The correlation coefficients between cash and stock dividends are substantiated in Panel C of Table IV. There are 25 cases where firms increased both cash and stock dividends, one case of no change in both cash and stock dividends, and four cases of decreases in both cash and stock dividends.

Further examination shows that firms did not increase cash dividends and decrease stock dividends at the same time, and they did not decrease cash dividends and maintain zero stock dividends. The percentage of firms that increased stock dividends and maintained zero cash 
dividends was 14 per cent whereas the percentage that decreased stock dividends and maintained zero cash dividends was only 4 per cent. However, 6 per cent of firms decreased both cash and stock dividends while 36 per cent increased both cash and stock dividends at the same time, respectively. Furthermore, 35 per cent of firms increased stock dividends and decreased cash dividends while no firm increased cash dividends and reduced stock dividends at the same time.

In summary, the number of firms (25) that increased both cash and stock dividends (thereby signalling their ability to maintain future earnings at current levels) is almost the same as the number of firms (24) that increased stock dividends and reduced cash dividends (thereby conserving their cash reserves). This suggests that Nigerian firms appear to use stock dividends both to signal their future earnings outlook as well as to substitute for cash dividends.

\section{Conclusions}

The study investigates the reaction of stock prices to stock dividend announcement from 2002 to 2006 for a sample of 60 companies listed on the Nigerian Stock Exchange. We employed the market model, following the method advocated by Seiler (2004) for the calculation of abnormal returns. Our findings indicate that stock prices in Nigeria react to announcements of stock dividends made outside the official stock exchange window, but not to early announcements. Like many emerging markets, the Nigerian stock market is characterised by thin trading, largely because many listed companies are owned by institutional investors that do not actively trade. As a result share price reactions may not fully reflect the impact of stock dividend announcements. To take account of this possibility we split our sample based upon trading frequency. Our results 
show that significant positive abnormal returns occur on the announcement day for companies with more actively traded stocks while significant negative abnormal returns occur on the announcement day for companies with less actively traded stocks. Olowe (1998) found similar results when investigating the share price reaction to the announcement of stock splits in Nigeria around ex-split dates. He argues that investors did not anticipate the event and so share prices did not adjust quickly after the split. However, he did not take into account the concentrated shareholding structure of listed companies and the fact that other corporate announcements are released alongside stock dividends.

We found that cumulative abnormal returns around the late announcement event date were statistically significant for both frequently and thinly traded stocks, suggesting that investors either anticipated the announcement or that the information may have leaked before the announcement day. However, the features of the Nigerian stock market and its microstructure suggest that the probability of information leakage might be higher than that of investor's anticipating the stock dividend announcement. When the Nigerian stock market matures to the extent that information is conveyed to all investors in a timely fashion it may be possible to establish whether the information content of stock dividends changes as a result, as in the study of the Turkish stock market by Aydogan and Muradoglu (1998).

On investigating the information content of stock dividend announcements we found evidence to justify both the signalling hypothesis, which argues that firms convey information about future earnings to investors through the announcement of stock dividends, and the cash substitution hypothesis, which suggests that firms issue stock dividends in place of cash dividends to 
conserve cash resources. Given the way in which announcements are disseminated to investors in the Nigerian stock market, in terms of their concurrent nature and timing, stock dividends do seem to be important in conveying information about a company's future earnings and cash resources. 


\section{Notes}

1. The market most examined in the substantive literature is the US but other markets studied include Australia, Canada, Denmark, Greece, Hong Kong, India, New Zealand, Portugal, Turkey and Nigeria.

2. Stock dividends in Nigeria are announced concurrently with cash dividends and earnings during the financial year-end for companies listed on the stock exchange. The Nigerian Stock Exchange requires all quoted companies to announce their audited financial statements at least three months after their respective accounting year-end.

3. The period 2002 to 2006 was chosen for our study because the start point marks five years after the Nigerian stock exchange computerised stock trading and the dissemination of corporate information in 1997, which facilitated the compilation of a database of stock prices and corporate actions.

4. Our study examined 99 stock dividend announcements from 2002 to 2006 . Although caution needs to be exercised when generalizing conclusions from a small sample size, the size of our sample compares favourably with those employed by other studies of stock dividends and stock splits in other developing stock markets. For example, Aydogan and Muradoglu (1998) used a sample of 109 stock dividend announcements in their study of the Turkish stock market over the period 1988 to 1993; Olowe (1998) in his study of the Nigerian stock market employed a sample of 86 stock split announcements covering the period 1981 to 1992; Dhar and Chhaochharia (2008) used a sample of 90 stock splits and 82 bonus issues announced by Indian companies listed on the Bombay Stock Exchange over the period 2001 to 2007; while Leledakis et. al. (2009) investigated 47 stock splits that occurred on the Greek stock market between 1990 and 2000.

5. Although the length of estimation and event periods varies across studies, the lengths chosen here are commonly applied in many event studies.

6. Dimson's Aggregate Coefficient method estimates the actual beta as the summation of the individual betas from a five period lead-lag regression of market returns on share price returns.

7. This is to determine the impact of trading frequency on stock dividend announcements, even though stock betas used in this study are Dimson-adjusted for infrequent trading.

8. When firms with zero dividends are omitted from the sample, the correlation coefficient increases to 0.2581 (significant at the $5 \%$ level).

9. Omitting firms with zero stock dividends increases the correlation to 0.088 (not significant at the $5 \%$ level). The correlation coefficient between earnings and stock dividends is lower than that between earnings and cash dividends. 


\section{BIBLIOGRAPHY}

Anderson, H., Cahan, S. and Rose, L. C. (2001), "Stock dividend in an imputation tax environment”, Journal of Business Finance and Accounting, Vol. 28 No. 5, pp. 653 - 669.

Aydogan, K. and Muradoglu, G. (1998), "Do markets learn from experience? Price reaction to stock dividends in the Turkish market”, Applied Financial Economics, Vol. 8, pp 41-49.

Balachandran, B., Faff, R. and Tanner, S. (2004), "Further evidence on the announcement effect of bonus shares in an imputation tax setting”, Global Finance Journal, Vol. 15 No. 2, pp. 147170.

Banker, R. D., Das, S. and Datar, S. M. (1993), “Complementarity of Prior Accounting Information: The Case of Stock Dividend Announcements”, The Accounting Review, Vol. 68 No. 1 , pp $28-47$.

Bechmann, K. L. and Raaballe, J. (2007), "The difference between stock splits and stock dividends: Evidence on the Retained earnings hypothesis”. Journal of Business Finance and Accounting, Vol. 34 Nos. 3 \& 4, pp. 574- 604.

Company and Allied Matters Act (1990), available at: http://www.nigerialaw.org/companiesandalliedmatterspartVI (accessed 14 July 2008).

Chen G., Firth M. and Gao, N. (2002), "The information content of concurrently announced earnings, cash dividends, and stock dividends: An investigation of the Chinese Stock Market”, Journal of International Financial Management and Accounting, Vol. 13 No. 2, pp. 101 - 24.

Dhar, S. and Chhaochharia, S. (2008), "Market reaction around the stock splits and bonus issues: some Indian evidence”. Electronic copy available at: http://ssrn.com/abstract=1087200

Doran, D. T., and Nachtmann, R. (1988). "The association of stock distribution announcements and earnings performance”, Journal of Accounting, Auditing \& Finance, Vol. 3, pp. 113 - 132.

Dimson, E. (1979), “Risk measurement when shares are subject to infrequent trading”, Journal of Financial Economics, Vol. 7, pp. 197-226.

Elfakhani, S. and Lung, T. (2003), “The effect of Split announcements on Canadian Stocks”, Global Finance Journal, Vol. 14, pp. 197- 216.

Fama, E. F., Fisher, L., Jensen, M. C. and Roll, R. (1969), “The adjustment of stock prices to new information”, International Economic Review, Vol. 10 No. 1, pp. 1 - 21.

Farinha, J. and Basilio, N. F. (2006), “Stock Splits: Real Effects or Just a Question of Maths? An Empirical Analysis of the Portuguese Case”. Electronic copy available at: http://www.fep.up.pt/investigacao/cete/papers/DP0608.pdf 
Ghosh, C. and Woolridge, J. R. (1989), "Stock market reaction to growth-induced dividend cuts: Are investors myopic”, Managerial and Decision Economics, Vol. 10 Issue 1, pp 25 - 35.

Grinblatt, M.S., Masulis, R.W., and Titman, S (1984), “The valuation effects of stock splits and stock dividends”, Journal of Financial Economics, Vol. 13 No. 4, pp. 461 - 90.

Ikenberry, D. L., Rankine, G. and Stice, E. K. (1996), “What do stock splits really signal?”, The Journal of Financial and Quantitative Analysis, Vol. 31 No. 3, pp. 357-75.

Lakonishok, J. and Lev, B. (1987), “Stock splits and stock dividends: Why, who and when”, The Journal of Finance, Vol. 42 No. 4, pp. 913- 32.

Lamoureux, C. G and Poon, P. (1987), “The market reaction to stock splits”, The Journal of Finance, Vol. 42 No. 5, pp. 1347-70.

Leledakis, G, Papaioannou, G. J., Travlos, N. G. and Tsangarakis, N. V. (2009), "Stock splits in a neutral transaction cost environment: Evidence from the Athens Stock Exchange", Journal of Multinational Financial Management, Vol. 19, pp. 12 - 25.

Leung, T.Y., Rui, O. M. and Wang, S. S. (2006), “Do stock splits really signal?”, FMA Annual Meeting. Electronic copy available at: http://www.fma.org/SLC/Papers/DoStockSplitsReallySignal.pdf

Liljeblom, E. (1989), "The informational impact of announcements of stock dividends and stock splits”, Journal of Business Finance and Accounting, Vol. 16 No. 5, pp. 681- 97.

Lyroudi, K. and Dasilas, A. (2006). "The valuation effects of stock splits in NASDAQ”, Managerial Finance, Vol. 32 No. 5, pp. 401 - 14.

McNichols, M. and Dravid, A. (1990), "Stock dividends, stock splits, and signalling”, The Journal of Finance, Vol. 45 No. 3, pp. 857 - 79.

Miller, M.H. and Modigliani, F. (1961), "Dividend policy, growth and the valuation of shares”, Journal of Business, Vol. 34 No. 4, pp. 411 - 33.

Olowe, R. A. (1998), "Stock splits and the efficiency of the Nigerian stock market", African Review of Money, Finance and Banking, Vols. 1-2, pp. 97 - 125.

Papaioannou, G.J., Travlos, N.G. and Tsangarakis, N.V. (2000), "Valuation effects of Greek Stock Dividend distributions”, European Financial Management, Vol. 6 No. 4, pp 515 - 31.

Seiler, M. J. (2004), Performing Financial Studies: A Methodological Cookbook, Pearson Education Inc., Upper Saddle River, New Jersey. 
Strong, N. (1992), "Modelling Abnormal Returns: A Review Article”, Journal of Business Finance \& Accounting, Vol. 19 No. 4, pp. 533 - 553.

Woolridge, R.J. (1983), “Ex-date stock price adjustment to stock dividends: A note”, The Journal of Finance, Vol. 38 No. 1, pp. 247 - 255. 